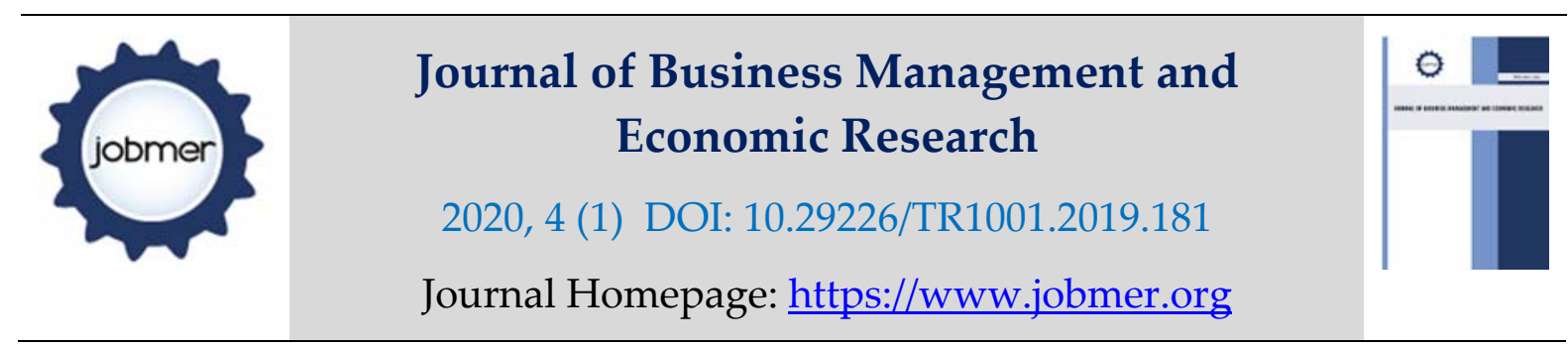

\title{
DO BOARD SIZE AND FIRM SIZE AFFECT ENVIRONMENTAL ACCOUNTING DISCLOSURE? EVIDENCE FROM SELECTED LISTED FIRMS IN KENYA
}

\author{
John Kipngetich Tarus \\ Department of Accounting and Finance, Moi University, Kenya \\ jktarus47@gmail.com
}

\begin{abstract}
The purpose of this study was to examine the effect of board size and firm size on environmental accounting disclosure in the Nairobi Securities Exchange, Kenya. The study's specific objectives were to determine the effect of board size and firm size on environmental accounting disclosure. The study was guided by the stakeholder's theory and longitudinal research design was adopted. The study targeted 27 selected listed firms from 2008 to 2017. The findings showed that board size had significant and negative impact on environmental accounting disclosure $(\beta=-0.328$, $p$-value $=0.001<0.05)$, while firm size had significant and positive impact on environmental accounting disclosure $(\beta=1.164, p$-value $=0.000<0.05)$. This implies that firms with larger boards are less likely to disclose environmental accounting information while large firms have high reporting on environmental information. The study recommends that firms listed in the Nairobi Securities Exchange ought to decrease board size while improving on assets so as to increase the level of environmental accounting disclosure in Kenyan firms.
\end{abstract}

Keywords; Board Size, Firm Size, Environmental Accounting Disclosure, and Stakeholders Theory.

\section{Introduction}

The environmental accounting disclosure, as promoted by Bowen (2009), is based on the analysis of the document. Several studies such as (Gray 2002; 2006; Gray \& Collison 2002; Sahay 2004; Byrch, et al., 2007) demonstrate environmental sustainability issues through reporting or perhaps disclosure of the environmental information. Although environmental disclosure is already a popular trend in large, small and medium-sized enterprises, its reporting does not address social issues (Sahay, 2004; Chan \& Welford, 2005). Indeed, it is a challenge for corporations with an environmental focus (Lamberton, 2005; Cho \& Patten, 2007). Chan \& Welford (2005) asserted that corporate accounting usually aims to reveal the good practices of the company to ensure the company's sustainability in order to contribute to the maximization of shareholder value, but nothing to do with the poor company practices of the

Tarus, J. K. (2020). Do Board Size and Firm Size Affect Environmental Accounting Disclosure? Evidence from Selected Listed Firms in Kenya. Journal of Business Management and Economic Research (JOBMER), Vol: 4, Issue:1, 21-37. 
environment. However, there is a danger of a false image of company reports being transmitted, highlighting those that are managed favorably (Lamberton, 2005).

According to Bassey et al., (2013), the motive of environmental accounting is to provide information for assessing the behavior of a company towards its environment and the economic impact of such action. Therefore, the environmental accounting system provides both financial information in financial units and non-financial information in physical units (Panigrahi, 2014). According to Ofoegbu, \& Megbuluba, (2016), environmental accounting covers all environmental information that involves environmental spending, product environmental advantages, and viable operational details. While Yakhou \& Dorweiler (2004) stated that the entire accounting field is covered by environmental accounting. Environmental accounting reports serve both inner and external information users. The information also enables managers to make pricing decisions, control overheads, and budgeting for capital. It offers the public and the economic community with information of interest (Beredugo \& Mefor, 2012).

Firms are anticipated to devote their efforts in environmental accounting and reporting practices so as to guarantee the stakeholders of their commitment to environmental responsibilities, compliance with national environmental legislation, compliance with financial reporting frameworks, demonstration of environmental concerns and disclosure of information to a broad spectrum of stakeholders (Beredugo \& Mefor, 2012; Ofoegbu, \& Megbuluba, 2016). Previous empirical studies on variables influencing the magnitude and quality of corporate social and environmental disclosure focused mainly on the effect of corporate attributes in two folds; the micro factors (firm size, industry, and financial performance) and the macro factors or the general contextual factors (social, political and economic context), while relatively little previous research has looked at the internal contextual variables that influence disclosure practices (Adams, 2002). Therefore, this study determined the effect of firm size and board size on environmental disclosure in Kenyan firms.

Environmental disclosure is an expensive practice and therefore bigger organizations are more likely to willingly invest resources to prepare and disclose environmental accounting, compared to small and medium corporations (Da Silva Monteiro \& Aibar-Guzmán, 2010). The assumption, suggested by Wong \& Fryxell, (2014) underlies this positive relationship. Large firms are becoming aware of the benefits of building and maintaining a good corporate reputation and those firms try to disclose its environmental accounting to safeguard or expand reputation. Furthermore, because of the polluting characteristics of their activities, companies operating in environmentally sensitive industries such as manufacturing must comply with strict environmental regulations (Da Silva Monteiro \& Aibar-Guzmán, 2010). According to (Cho \& Patten, 2007; Clarkson et al., 2008), companies operating in these delicate sectors 
should, therefore, reveal their environmental concerns otherwise, the worst will be assumed by stakeholders and particularly investors.

The relationship between business organizations and their environment in contemporary times has witnessed drastic changes. Environmental and social issues over the years have not been seriously considered in management objectives (Pereira Eugenio et al., 2013), this is simply because they were deemed to have no significant economic impact. But in a bid to gain legitimacy, most organizations have now embraced the relevance of their environment to their businesses and the need to safeguard it. Studies showed that many organizations failed not because they lack resources or because of defective products, but due to a complete loss or deterioration of their legitimacy (Díez-Martín et al., 2013).

Environmental pollution has been a common problem in Kenya in the last few decades due to the growth of industries. However, the growth of industries can cause problems, particularly to the environment (Pratten \& Mashat, 2009). This, in turn, leads to increasing demands for enhancing corporate accountability and social responsibility in business practices (Rahman, 2013; Byron, 2015). The need for companies to be socially responsible cannot be ignored and can be seen in the light of several benefits such as being a sustainable company, improving relations with governments and other regulatory bodies, improving reputation (World Business Council for Sustainable Development, 2012).

However, despite social accounting and reporting being a new phenomenon and the lack of any mandatory regulation towards this disclosure in Kenya, companies are voluntarily engaged in reporting several social responsibility activities in their annual financial reports and it appears that companies have progressed substantially further than literature. While many studies on social and environmental accounting and reporting on corporate social responsibility have been carried out, few studies have been carried out to determine the impact of board size and firm size on environmental accounting disclosure among selected companies in the Nairobi Securities Exchange.

\section{Theoretical Framework}

The study was based on Stakeholder theory. Stakeholder theory has been commonly used in accounting literature as a powerful justification for corporate social and environmental disclosure methods as well as mechanisms for corporate governance. Stakeholder's theory encompasses recognizing and identifying the relationship between the conduct of the company and the effect on its stakeholders (Ansoff, 1965). Furthermore, the continued existence of the corporation needs stakeholder support and 
its approval must be sought and the corporation's operations adjusted to obtain that permission. The stronger the stakeholders, the more the firm must adapt in society (Gray et al., 1995).

The stakeholder theory's primary benefit is to provide a means to deal with various stakeholders with multiple conflicting interests. According to Freeman, (1984), indicated that the satisfaction of the various stakeholder's interests is accomplished through system-centered theory. In the context of corporate social responsibility research, stakeholder theory appears to offer a new perspective by suggesting that shareholder requirements cannot be met without meeting other stakeholder's needs (Foster \& Jonker, 2005; Jamali, 2008). The stakeholder theory, therefore, offers a helpful mechanism for assessing social and environmental reporting practices of companies. (Snider et al., 2003).

The stakeholder theory's fundamental proposition is that the result of the effective leadership of the company's interactions with stakeholders determines the achievement of the firm (Elijido-Ten, 2004). In this case, the stakeholders are identified by the organization of concern by a perceived strategic need to manage particular relationships to achieve their aims (Uwuigbe, 2011). A foundation for stakeholder theory is that businesses are so big and their effect on society is so persuasive that many more sectors of society should be held accountable than shareholders alone. Shareholders are not only influenced by businesses, but they also impact businesses in the same manner (Jill, 2007).

The stakeholder theory's policy view treats all the company's stakeholders equally and does not take into consideration each stakeholder's authority (Ali \& Rizwan, 2013). In addition, the stakeholder theory argues that executives should work for the benefit of all stakeholders. With respect to the organizational viewpoint of stakeholder theory, it takes into account the needs of a limited number of stakeholders, who have a significant influence on the company. Furthermore, the strength of the business heavily relies on the nature of the shareholder's funds or resources (Deegan and Unerman, 2006).

The theory supports the idea that the behavior of various stakeholder groups is what encourages management to match corporate needs with their surroundings (Barako \& Brown, 2008). The managerial branch of stakeholder theory provides a framework in which to analyze corporate social environmental disclosure in an organization centered way. The achievement of handling stakeholders properly through corporate environmental disclosure enables firms not only gain legitimacy but also credibility (Van Der Laan, 2009). According to stakeholder theory, the economic performance of a firm has a positive effect on voluntary environmental and social disclosure (Cormier \& Magnan, 2003; Ho \& Taylor 2007) and on investment in social responsibility (Cho \& Patten, 2007). 


\subsection{Hypothesis Development (Literature Review)}

Firm size and board size appear as control variables in various empirical finance studies. For example, they are used as control variables in default forecast models (Shumway, 2001). In this study, they were used to determine its effects on environment accounting disclosure in Kenyan firms. However, several empirical studies have found significant evidence that there is a positive relationship between company size and the level of social and environmental disclosure (Cowen et al., 1987; Patten, 1992; Gray et al., 1995; Hackston \& Milne, 1996; Patten, 2002; Brammer \& Pavelin, 2006; Milanés-Montero et al., 2011; Suttipun \& Stanton, 2012; Zeng et al., 2012). These studies argued that bigger firms are visible and exposed because of their size and image. Therefore, larger firms are more willing to disclose information about the environment to satisfy their massive stakeholders. In turn, they are likely to seek out resources and thus reveal environmental information to alter the perception of society. Again bigger firms are more prone to disclose environmental accountings than smaller firms to avoid punitive measures from regulators and reduce the risk of the regulation (Burgwal \& Vieira, 2014). Brammer \& Pavelin, (2008) study the quality of voluntary disclosures in the UK's industrial sector and analyzed the determinants of the disclosure. Findings revealed that larger companies and the complexity of their operations affect the quality of disclosures.

Prior research has attempted to explain why firm size is directly related to disclosure of the environment. The first justification for this is the cost of producing environmental information. It is argued that the expense incurred in disclosing environmental accounting is high, that small company cannot afford with their limited resources (Da Silva Monteiro \& Aibar-Guzmán, 2010). Therefore, larger companies might have sufficient resources to afford the cost of reporting information for the users of their annual reports. Secondly, agency cost is higher for large firms not to report on their environmental activities because their shareholders are widespread (Watts \& Zimmerman, 1983; Zeng et al., 2012; Christ \& Burritt, 2013). Thus, disclosing more information reduces potential agency costs. Thirdly, the literature suggests that larger companies tend to disclose more environmental information than smaller companies in their annual reports due to their competitive cost advantage (Lang \& Lundholm, 1993; Lobo \& Zhou, 2001; Kolk, 2003).

The size of the firm is operationalized using a number of measures, such as sales, total assets, and the number of employees. The majority of the empirical studies have found significant evidence that there is a positive relationship between company size and the level of social and environmental disclosure (Cowen et al., 1987; Patten, 1992; Gray et al., 1995; Hackston \& Milne, 1996; Patten, 2002; Brammer \& Pavelin, 2006; Milanés-Montero et al., 2011; Suttipun \& Stanton, 2012; Zeng et al., 2012). Therefore, a 
positive relationship is predicted between firm size and the level of environmental disclosure. This is also consistent with the stakeholder theory, which claims that stakeholders have the opportunity to control the resources of a company. Larger organizations have more stakeholders and therefore they are more likely to satisfy their stakeholders, in order to keep them operating.

A number of studies over the past decades have successfully tested the influence of firm size on environmental disclosures. These studies have found that the overall level of social and environmental disclosure is positively associated with the size of the company (Patten, 1992; Gray et al., 1995; Deegan \& Gordon, 1996; Hackston and Milne, 1996; Choi, 1999; Al-Tuwaijri et al., 2004; Freedman \& Jaggi, 2005; Gao et al., 2005; Brammer \& Pavelin, 2008; Haddock-Fraser \& Fraser, 2008; García-Sanchez, 2008; Stanny \& Ely, 2008). However, Patten (2002) found that firm size may not be a critical determining factor in corporate environmental reporting. The underlying assumption is that there is a positive relationship between firm size and the level of environmental disclosure. Several reasons have been argued in support of this positive relationship. Firstly, according to Schipper, 1991; Deegan \& Gordon, 1996), large companies are usually exposed to greater attention from stakeholders in relation to their environmental performance than smaller firms and, therefore, they face greater pressures to disclose more information than smaller firms.

Further, as suggested by Wong \& Fryxell, (2004), as a result of the increased awareness and concern about environmental issues, large companies are interested in projecting an image of themselves as firms engaged in the protection of the environment and, in this sense, they consider the disclosure of environmental information as a way to enhance the company's public image and reputation. On the other hand, the preparation and disclosure of environmental information are costly and, in comparison to medium and small firms, larger companies can afford to spend the financial and technical resources that are necessary to prepare and disclose environmental information and, consequently, it is more likely that they provide such information (Wong \& Fryxell, 2004).

Previous studies have indicated inconsistency results about the relationship between the board size and the level of environmental disclosure (Mahmood, et al., 2018), while some studies indicate a positive relationship between the board size and the level of environmental disclosure (Ienciu, 2012; Bajahar \& Al-Hajili, 2017; Mahmood et al., 2018). Victor \& Fodio, (2012) noted that the increase in board size may entail additional cost, which results in the difficulty of communication between members, and that weaker decisions are usually associated with large groups. In addition, the increase in the number of members involves a weakness in control. This is as a result of the differences of views among its 
members. Since there are a number of studies that indicated the absence of this relationship (Ienciu, 2012; Htay et al., 2012).

Recent empirical evidence from an emerging economy by Trireksani \& Djajadikerta, (2016) examined the relationship between corporate governance variables and the extent of environmental disclosure. The study focused only on mining companies listed in Indonesia Stock Exchange and employed content analysis of the annual reports and documents a significant positive association between the board size and the extent of environmental disclosure. Osazuwa et al., (2016) utilized a cross-section data of sample size of 116 firms in Nigeria and provided evidence that board size positively relates to the level of environmental disclosure. Further, the quality of climate change disclosure results showed a positive association between board effectiveness and the firm's decision (Ben-Amar \& Mcllkenny, 2015). Bridging the gap in knowledge about the relationship between corporate governance and corporate social responsibility (CSR) in the banking sector of the US, Jizi et al., (2013) found a significant positive association between board size and corporate social reporting.

Jizi, et al., (2015) used meta-analysis to a sample of 64 empirical studies to identify possible determinants to the relationship between the board, audit committee characteristics and voluntary disclosure. The study acknowledged that board size revealed a significant positive effect on voluntary disclosure. The large composition of the board is perceived to be capable of influencing the extent to which corporate entities disclose their activities in any environment (Haniffa \& Cooke, 2005; Ntim \& Osei, 2011). Bhagat \& Bolton (2008) supported by agency theory (John \& Senbet, 1998) argued that due to the diversity of expertise of members, environmental disclosure is expected to be high (Xie et al., 2003; Sun, Salama, Hussainey, \& Habbash, 2010; Allegrini \& Greco, 2011). Some of the studies conducted in both developed and developing countries revealed a positive association between board size and environmental impact disclosures (Andrikopoulos \& Kriklani, 2013; Khlif et al., 2015) while some showed negative relationship Uwuigbe, (2011) and others insignificant results (Halme \& Huse, 1997; Cheng \& Courtenay, 2006).

The major criticism of previous literature on corporate environmental responsibility disclosures is that the results tend to be inconsistent and inconclusive. Inconsistency may be attributed to a lack of theory, diversity of empirical databases examined and the absence of a single conceptual framework to analyze the required relationships (Belkaoui \& Karpik, 1989). In addition, the lack of any explicit comprehensive environmental responsibility theory underpinning the analysis performed and sufficient to explain why corporations engage in social responsibility endeavors (Roberts, 1992). The probability still insufficiently specified theories that exist (Gray et al., 2001). Existing evidence regarding the influence 
upon the propensity for firms to make voluntary environmental disclosures suffers from well-known limitations (Ullmann, 1985; Patten, 2002) that contribute to the inconclusiveness of existing findings (Gray et al., 2001). These limitations concern the dimensions, types, and proxies of each of the dependent variables and independent variables, the different control variables and their proxies, the sample size and type, the years and time spans, and the method of estimating relationships. Prior studies examined the determinants of corporate environmental disclosure are mainly cross-sectional in nature investigating the relationship over one year only (Adams, 2002; Brammer \& Pavelin, 2006) except for very few studies (Barako et al., 2006; Campbell, 2004; Gray et al., 2001). The current study contributes to the disclosure literature by hypothesizing that;

\section{H1: Firms with large board size have a high probability of Environmental Accounting Disclosure}

\section{H2: Large firms have a high probability of Environmental Accounting Disclosure}

\section{Methodology}

This study adopted a longitudinal research design where the observation of the same items are repeated over long periods of time (Sekaran, 1992). Furthermore, the study used a positivist approach (Saunders et al., 2011; Kumar, 2019) while the document analysis guide was utilized as a data collection instrument. The study was conducted using secondary sources which were achieved by analyzing the content of financial reports of 27 selected firms quoted in NSE. This is suitable for this study because all the audited annual financial information about the companies is readily available for the public as mandated by the company's Act.

\subsection{Measurement of Variables}

Corporate environmental disclosure scores (EDS) are measured using a content analysis of the company's annual report for a period of 10 years from 2008 to 2017. An environmental disclosure index (EDI) is adapted from the Global Reporting Initiative (GRI, 2008) consisting of 22 items. The overall goal of the GRI is to develop a globally accepted reporting framework to enhance the quality, rigor, and utility sustainability reporting. It is argued that the GRI framework and its environmental dimension comprehensively enhance a better understanding of environmental disclosure in this vibrant economic sector (Clarkson, et al., 2008; Dragomir, 2010).

Furthermore, based on the Global Reporting Initiative (GRI, 2008), environmental disclosure score (EDS) was calculated by assigning dummy scores depending on the existence and specificity of information. The value of the of 1 was assigned if the firm discloses information on the particular item or otherwise 0 . In addition, the EDS value was determined for each corporation as the ratio of the 
estimated total disclosure scores to the maximum possible scores (total number of items included in the index). In this study, board size was determined by taking the number of directors sitting on the board (Jehn \& Bezrukova, 2004; Roberson \& Park, 2007). While, the natural logarithm of total assets was used to measure firm size variable (Henry, 2010).

\subsection{Analytic Model}

The study employed a panel data framework to test the hypotheses. Panel data was analyzed using a fixed-effect model and a random-effects model. Hausman test was conducted to decide whether the fixed effect or the random effect is the appropriate model to explain the relationship between variables. The hypothesis was tested using a linear regression model as specified in the equation below;

$E A D_{i t}=\beta_{0 i \mathrm{t}}+\beta_{1 \mathrm{it}} \mathrm{BS}_{1 \mathrm{it}}+\beta_{2 \mathrm{it}} \mathrm{FS}_{2 \mathrm{it}}+\varepsilon$

Where;

$\boldsymbol{E} \boldsymbol{A D}=$ Environmental accounting disclosure

$\boldsymbol{\beta}_{\mathbf{0}}=$ Beta coefficient

$\boldsymbol{B S}=$ Board Size

$\boldsymbol{F} \boldsymbol{S}=$ Firm size

$\boldsymbol{\varepsilon}=$ Random error term

\section{Findings and Discussions}

Descriptive statistics for the dependent, independent and test variables are presented in Table 1. Using a scoring system to develop an EDI, consistent with previous studies, the results indicated that the mean value of environmental accounting disclosure ranged from a minimum of 0.06 to a maximum of 0.87 . The average value for environmental accounting disclosure was 0.526 . Despite the fact that the level of environmental accounting disclosed is low, the extent of environmental disclosure between 2008 and 2017 has increased as well as the number of Kenyan companies disclosing environmental information. Indeed, despite the low average value of the environmental disclosure index, it has positively evolved, both overall and in each industry. Therefore, it can be asserted that the Kenyan firms' environmental reporting practices have improved over the studied period of time, although their level of environmental disclosure still lags behind those of other developed countries. The board had a minimum of 2 members and a maximum of 19. While, on average, the board composed of 9 members (mean $=9.422$ ). Furthermore, the firm size was at a mean of 9.681 with a minimum of 8.25 and a 
maximum of 11.28. The correlation results showed that board size and firm size have a significant correlation with environmental accounting disclosure.

Table 1: Descriptive and Correlation Results

\begin{tabular}{lccccccccc}
\hline Stats & Obs & Min & Iqr & Max & Mean & SD & EAD & BS & FS \\
\hline EAD & 270 & 0.06 & 0.45 & 0.87 & 0.526 & 0.215 & 1 & & \\
BS & 270 & 2 & 7 & 19 & 9.422 & 3.642 & $-0.32^{* *}$ & 1 & \\
FS & 270 & 8.25 & 0.73 & 11.28 & 9.681 & 0.601 & $-0.40^{* *}$ & $-0.39 *$ & 1 \\
\hline ** Correlation is significant at the 0.01 level (2-tailed). & & & & \\
$*$ Correlation is significant at the 0.05 level (2-tailed). & & & &
\end{tabular}

\subsection{Testing for Hypotheses}

The study utilized a random and fixed effect model to test the hypotheses as depicted in Table 2. Based on the Hausman test results, the study hypotheses utilized a random effect model. The random effect results were used in the final analysis to overcome the shortcomings associated with the fixed effect results (Wachira, 2017). As Kohler \& Kreuter, (2009) suggest, the random effect estimator handles better models that contain time-invariant variables that are usually omitted by the fixed-effects model. The results of R-square of 0.188 reveal a strong strength of the relationship between the model and the study variables, indicating that approximately $18.8 \%$ of the variation in the output can be explained by the independent variables in the model. Furthermore, this relationship is statistically significant since the F value (Wald chi2 $(2)=61.98, \mathrm{p}<0.05)$ of the model is significant at the 0.05 level.

Based on the statistical findings, board size revealed $(\beta=-0.328, p=0.000<0.05)$, implying that a large board decreases environmental disclosure in Kenyan firms. In addition, the results from a random effect model showed that firm size has a significant effect on environmental accounting disclosure of selected listed firms in Nairobi Securities Exchange $(\beta=1.164, p=0.000<0.05)$, indicating that large firms are likely to improve their level of environmental disclosure. 
Table 2. Fixed and Random Effect Models

\begin{tabular}{|c|c|c|c|c|c|c|}
\hline \multirow[b]{2}{*}{ EAD } & \multicolumn{2}{|c|}{ Random Effect } & \multicolumn{4}{|c|}{ Fixed Random } \\
\hline & Coef. & Std. Err. & $\mathbf{P}>\mathbf{z}$ & Coef. & Std. Err. & $P>t$ \\
\hline $\mathrm{BS}$ & -0.328 & 0.102 & 0.001 & -0.412 & 0.155 & 0.008 \\
\hline FS & 1.164 & 0.219 & 0.000 & 1.169 & 0.250 & 0.000 \\
\hline _cons & -2.529 & 0.622 & 0.000 & -2.362 & 0.785 & 0.003 \\
\hline \multicolumn{7}{|l|}{$\overline{\mathrm{R}}$-sq: } \\
\hline Within & 0.178 & & & 0.1784 & & \\
\hline between & 0.322 & & & 0.3221 & & \\
\hline Overall & 0.188 & & & 0.1875 & & \\
\hline Wald chi2(2) & $=$ & $61.98 *$ & & $F(2,241)$ & \multicolumn{2}{|c|}{$26.17 * *$} \\
\hline \multicolumn{7}{|c|}{ Hausman test } \\
\hline \multicolumn{7}{|c|}{$\begin{array}{l}\mathrm{b}=\text { consistent under Ho and Ha; obtained from xtreg } \\
\text { nconsistent under Ha, efficient under Ho; obtained from xtreg } \\
\text { difference in coefficients not systematic } \\
\text { hi2 }(2)=(\mathrm{b}-\mathrm{B})^{\prime}\left[\left(\mathrm{V} \_\mathrm{b}-\mathrm{V} \_\mathrm{B}\right)^{\wedge}(-1)\right](\mathrm{b}-\mathrm{B})\end{array}$} \\
\hline \multicolumn{3}{|c|}{ Prob $>$ chi $2=$} & & & & \\
\hline
\end{tabular}

** Significant at the 0.01 level (2-tailed).

* Significant at the 0.05 level (2-tailed).

\section{Conclusion and Recommendation}

This study looked at the effect of board size and firm size on corporate environmental disclosure among firms listed in Kenya. The study came up with interesting findings that are of salient importance to scholars investigating corporate governance issues in the Kenyan context. In accordance with the first hypotheses, the study observed that lager board size in a firm had a negative impact on the level of environmental disclosure. This is consistent with the resource dependence theory, which posits that independent boards enhance corporate image and ensure shareholders' interest. In the second hypothesis, the study however observed that there is a significant positive relationship between firm size and the level of environmental disclosure. This result is however in line with the suggestions of the agency theory. That is, increasing the firm asset will lead to better corporate environmental disclosure. Finally, this paper, therefore, calls for further longitudinal studies that will provide insights into some reporting patterns among listed firms in the country. 


\section{Reference}

Adams, C. A. (2002). Internal organizational factors influencing corporate social and ethical reporting: Beyond current theorizing. Accounting, Auditing \& Accountability Journal, 15(2), 223-250.

Ali, W., \& Rizwan, M. (2013). Factors influencing corporate social and environmental disclosure (CSED) practices in the developing countries: An institutional theoretical perspective. International Journal of Asian Social Science, 3(3), 590-609.

Allegrini, M., \& Greco, G. (2013). Corporate boards, audit committees and voluntary disclosure: Evidence from Italian listed companies. Journal of Management \& Governance, 17(1), 187-216.

Al-Tuwaijri, S. A., Christensen, T. E., \& Hughes Ii, K. E. (2004). The relations among environmental disclosure, environmental performance, and economic performance: a simultaneous equations approach. Accounting, Organizations and Society, 29(5-6), 447-471.

Andrikopoulos, A., \& Kriklani, N. (2013). Environmental disclosure and financial characteristics of the firm: The case of Denmark. Corporate Social Responsibility and Environmental Management, 20(1), 55-64.

Ansoff, H. I. (1965). Corporate strategy: business policy for growth and expansion. McGraw-Hill Book.

Bajahar, M. S., \& al-Hajili, A. H. (2017). The impact of the Board of Directors' structure on the level of voluntary disclosure in cement companies listed on the Saudi Stock Exchange. Arab Journal of Administrative Sciences, 24(3), 383-410.

Barako, D. G., \& Brown, A. M. (2008). Corporate social reporting and board representation: evidence from the Kenyan banking sector. Journal of Management \& Governance, 12(4), 309.

Barako, D. G., Hancock, P., \& Izan, H. Y. (2006). Factors influencing voluntary corporate disclosure by Kenyan companies. Corporate Governance: an international review, 14(2), 107-125.

Bassey, B. E., Effiok, S. O., \& Eton, O. E. (2013). The impact of environmental accounting and reporting on organizational performance of selected oil and gas companies in Niger Delta Region of Nigeria. Research Journal of Finance and Accounting, 4(3), 57-73.

Belkaoui, A., \& Karpik, P. G. (1989). Determinants of the corporate decision to disclose social information. Accounting, Auditing \& Accountability Journal, 2(1).

Ben-Amar, W., \& Mcllkenny, P. (2015). Board effectiveness and the voluntary disclosure of climate change information. Business Strategy and the Environment, 24(8), 704-719.

Beredugo, S. B., \& Mefor, I. P. (2012). The Impact of environmental accounting and reporting on sustainable development in Nigeria. Research Journal of Finance and Accounting, 3(7), 55-63.

Bhagat, S., \& Bolton, B. (2008). Corporate governance and firm performance. Journal of corporate finance, 14(3), 257-273.

Bowen, G. A. (2009). Document analysis as a qualitative research method. Qualitative research journal, 9(2), 27-40.

Brammer, S., \& Pavelin, S. (2008). Factors influencing the quality of corporate environmental disclosure. Business Strategy and the Environment, 17 (2), 120-136.

Brammer, S., Brooks, C., \& Pavelin, S. (2006). Corporate social performance and stock returns: UK evidence from disaggregate measures. Financial management, 35(3), 97-116.

Burgwal, D. V. D., \& Vieira, R. J. O. (2014). Environmental disclosure determinants in Dutch listed companies. Revista Contabilidade \& Finanças, 25(64), 60-78. 
Byrch, C., Kearins, K., Milne, M., \& Morgan, R. (2007). Sustainable "what"? A cognitive approach to understanding sustainable development. Qualitative Research in Accounting \& Management, 4(1), 26-52.

Byron, R. K. (2015). Corporate Sector to be Accountable to JS. The Daily Star, 9 March.

Campbell, D. (2004). A longitudinal and cross-sectional analysis of environmental disclosure in UK companies a research note. The British Accounting Review, 36(1), 107-117.

Chan, J. C. H., \& Welford, R. (2005). Assessing corporate environmental risk in China: an evaluation of reporting activities of Hong Kong listed enterprises. Corporate Social Responsibility and Environmental Management, 12(2), 88-104.

Cheng, E. C., \& Courtenay, S. M. (2006). Board composition, regulatory regime, and voluntary disclosure. The International Journal of accounting, 41(3), 262-289.

Cho, C. H., \& Patten, D. M. (2007). The role of environmental disclosures as tools of legitimacy: A research note. Accounting, organizations and society, 32(7-8), 639-647.

Choi, J.S., 1999. An investigation of the initial voluntary environmental disclosures made in Korean semi-annual financial reports. Pacific Accounting Review 11(1), 73-102.

Christ, K. L., \& Burritt, R. L. (2013). Environmental management accounting: the significance of contingent variables for adoption. Journal of Cleaner Production, 41, 163-173.

Clarkson, P. M., Li, Y., Richardson, G. D., \& Vasvari, F. P. (2008). Revisiting the relation between environmental performance and environmental disclosure: An empirical analysis. Accounting, organizations and society, 33(4-5), 303-327.

Cormier, D., \& Magnan, M. (2003). Environmental reporting management: a continental European perspective. Journal of Accounting and Public Policy, 22(1), 43-62.

Cowen, S. S., Ferreri, L. B., \& Parker, L. D. (1987). The impact of corporate characteristics on social responsibility disclosure: A typology and frequency-based analysis. Accounting, Organizations and Society, 12(2), 111-122.

Da Silva Monteiro, S. M., \& Aibar-Guzmán, B. (2010). Determinants of environmental disclosure in the annual reports of large companies operating in Portugal. Corporate Social Responsibility and Environmental Management, 17(4), 185-204.

Deegan, C. \& Unerman (2006). Corporate Legitimacy and Environmental Reporting - Deegan and Underman Contentions", Accounting Research Blog,

Deegan, C., \& Gordon, B. (1996). A study of the environmental disclosure practices of Australian corporations. Accounting and Business Research, 26(3), 189-199.

Díez-Martín, F., Prado-Roman, C., \& Blanco-González, A. (2013). Beyond legitimacy: legitimacy types and organizational success. Management Decision, 51(10), 1954-1969.

Dragomir, V. D. (2010). Environmentally sensitive disclosures and financial performance in a European setting. Journal of Accounting \& Organizational Change, 6 (3), 359-388.

Elijido-Ten, E. (2004, July). Determinants of environmental disclosures in a developing country: an application of the stakeholder theory. In Fourth Asia Pacific interdisciplinary research in accounting conference, Singapore (pp. 4-6).

Foster, D., \& Jonker, J. (2005). Stakeholder relationships: the dialogue of engagement. Corporate Governance: The International journal of business in society, 5(5), 51-57. 
Freedman, M., \& Jaggi, B. (2005). Global warming, commitment to the Kyoto protocol, and accounting disclosures by the largest global public firms from polluting industries. The International Journal of Accounting, 40(3), 215-232.

Freeman, R. E. 1984. Strategic management: A stakeholder approach. Boston: Pitman.

Gao, S. S., Heravi, S., \& Xiao, J. Z. (2005, June). Determinants of corporate social and environmental reporting in Hong Kong: a research note. In Accounting Forum 29 (2), 233-242.

García-Sánchez, I. M. (2008). Corporate social reporting: Segmentation and characterization of Spanish companies. Corporate Social Responsibility and Environmental Management, 15(4), 187-198.

Gray, R. (2002). Of messiness, systems and sustainability: towards more social and environmental finance and accounting. The British Accounting Review, 34(4), 357-386.

Gray, R. (2006). Does Sustainability Reporting Improve Corporate Behaviour? Wrong Question? Right Time? Accounting and Business Research, 65-88.

Gray, R., \& Collison, D. (2002). Can't see the wood for the trees, can't see the trees for the numbers? Accounting education, sustainability and the public interest. Critical Perspectives on Accounting, 13(5-6), 797-836.

Gray, R., Javad, M., Power, D. M., \& Sinclair, C. D. (2001). Social and environmental disclosure and corporate characteristics: A research note and extension. Journal of business finance $\mathcal{E}$ accounting, 28(3-4), 327-356.

Gray, R., Kouhy, R., \& Lavers, S. (1995). Corporate social and environmental reporting: A review of the literature and a longitudinal study of UK disclosure. Accounting, Auditing and Accountability Journal, 8(2), 47-77.

Hackston, D., \& Milne, M. J. (1996). Some determinants of social and environmental disclosures in New Zealand companies. Accounting, Auditing and Accountability Journal, 9(1), 77-108.

Haddock-Fraser, J., \& Fraser, I. (2008). Assessing corporate environmental reporting motivations: differences between 'close-to-market' and 'business-to-business' companies. Corporate Social Responsibility and Environmental Management, 15(3), 140-155.

Halme, M., \& Huse, M. (1997). The influence of corporate governance, industry and country factors on environmental reporting. Scandinavian Journal of Management, 13(2), 137-157.

Haniffa, R. M., \& Cooke, T. E. (2005). The impact of culture and governance on corporate social reporting. Journal of accounting and public policy, 24(5), 391-430.

Henry, D. (2010). Agency costs, ownership structure and corporate governance compliance: A private contracting perspective. Pacific-Basin Finance Journal, 18(1), 24-46.

Ho L. C., \& Taylor, M. E. (2007). An empirical analysis of triple bottom-line reporting and its determinants: evidence from the United States and Japan. Journal of International Financial Management \& Accounting, 18(2), 123-150.

Htay, S. N., Rashid, H. M., Adnan, M. A., \& Meera, A. K. (2012). Impact of Corporate Governance on Social and Environmental Information Disclosure of Malaysian Listed Banks: Panel Data Analysis. Asian Journal of Finance and Accounting, 1(4), 1-24.

Ienciu, I. A. (2012). The relationship between environmental reporting and corporate governance characteristics of Romanian listed entities. Accounting and Management Information Systems, 11(2), 267-294. 
Jamali, D. (2008). A stakeholder approach to corporate social responsibility: A fresh perspective into theory and practice. Journal of business ethics, 82(1), 213-231.

Jehn, K. A., \& Bezrukova, K. (2004). A field study of group diversity, workgroup context, and performance. Journal of Organizational Behavior: The International Journal of Industrial, Occupational and Organizational Psychology and Behavior, 25(6), 703-729.

Jill, S., (2007). Corporate Governance and Accounting, 1' Edition", John Wiley and Sons Publisher, England.

Jizi, M. (2013). Corporate governance, disclosure content and shareholder value: Impacts and interrelationships from the US Banking Sector (Doctoral dissertation, Durham University).

Jizi, M. (2015). How banks' internal governance mechanisms influence risk reporting. Corporate Ownership and Control, 12(3), 55-72.

John, K., \& Senbet, L. W. (1998). Corporate governance and board effectiveness. Journal of Banking $\mathcal{E}$ Finance, 22(4), 371-403.

Khlif, H., Hussainey, K., \& Achek, I. (2015). The effect of national culture on the association between profitability and corporate social and environmental disclosure: A meta-analysis. Meditari Accountancy Research, 23(3), 296-321.

Kohler, U., \& Kreuter, F. (2009). Data analysis using Stata (2nd ed.). College Station: Stata Press.

Kolk, A. (2003). Trends in sustainability reporting by the fortune global 250. Business Strategy and the Environment, 12(5), 279-291.

Kumar, R. (2019). Research methodology: A step-by-step guide for beginners. Sage Publications Limited.

Lamberton, G. (2005). Sustainability Accounting - a Brief History and Conceptual Framework. Accounting Forum, 29(1), 7-26.

Lang, M., \& Lundholm, R. (1993). Cross-sectional determinants of analyst ratings of corporate disclosures. Journal of accounting research, 31(2), 246-271.

Lobo, G. J., \& Zhou, J. (2001). Disclosure quality and earnings management. Asia-Pacific Journal of Accounting \& Economics, 8(1), 1-20.

Mahmood, Z., Kouser, R., Ali, W., Ahmad, Z., \& Salman, T. (2018). Does corporate governance affect sustainability disclosure? A mixed methods study. Sustainability, 10(1), 207.

Milanés-Montero, Patricia - Pérez-Calderón, Esteban. (2011), Corporate Environmental Disclosure and Legitimacy Theory: An Europe Perspective, Environmental Engineering \& Management Journal (EEMJ), 10(12).

Ntim, C. G., \& Osei, K. A. (2011). The impact of corporate board meetings on corporate performance in South Africa. African Review of Economics and Finance, 2(2), 83-103.

Ofoegbu, G. N., \& Megbuluba, A. (2016). Corporate environmental accounting information disclosure in the Nigeria manufacturing firms. International journal of management sciences and business research, 5(12).

Osazuwa, N. P., Ahmad, A. C., \& Che-Adam, N. (2016). Financial performance in Nigerian quoted companies: The influence of political connection and governance mechanisms. International Journal of Economics and Financial Issues, 6(7), 137-142. 
Panigrahi, S. K., Zainuddin, Y., \& Azizan, A. (2014). Comparing traditional and economic performance measures for creating shareholder's value: a perspective from Malaysia. International Journal of Academic Research in Accounting, Finance and Management Sciences, 4(4), 280-289.

Patten, D. M. (1992). Intra-industry environmental disclosures in response to the Alaskan oil spill: a note on legitimacy theory. Accounting, organizations and Society, 17(5), 471-475.

Patten, D. M. (2002). The relation between environmental performance and environmental disclosure: a research note. Accounting, organizations and Society, 27(8), 763-773.

Pereira Eugénio, T., Costa Lourenço, I., \& Morais, A. I. (2013). Sustainability strategies of the company TimorL: extending the applicability of legitimacy theory. Management of Environmental Quality: An International Journal, 24(5), 570-582.

Pratten, J. D., \& Abdulhamid Mashat, A. (2009). Corporate social disclosure in Libya. Social Responsibility Journal, 5(3), 311-327.

Rahman, M. S. (2013). Auditors' Compromise Blocks Good Corporate Governance. The Daily Star 5th July.

Roberson, Q. M., \& Park, H. J. (2007). Examining the link between diversity and firm performance: The effects of diversity reputation and leader racial diversity. Group $\mathcal{E}$ Organization Management, $32(5), 548-568$.

Roberts, R. W. (1992). Determinants of corporate social responsibility disclosure: An application of stakeholder theory. Accounting, organizations and society, 17(6), 595-612.

Sahay, A. (2004). Environmental reporting by Indian corporations. Corporate Social Responsibility and Environmental Management, 11(1), 12-22.

Saunders, M. N. (2011). Research methods for business students, 5/e. Pearson Education India.

Schipper, K. (1991). Commentary on Analysts. Accounting Horizons, 5(4), 105-121.

Sekaran, U. (1992). Research Methods for Business - A skill-building approach. (2nd Ed). United States of America: John Wiley \& Sons, Inc.

Shumway, T. (2001). Forecasting bankruptcy more accurately: A simple hazard model. The journal of business, 74(1), 101-124.

Snider, J., Hill, R. P., \& Martin, D. (2003). Corporate social responsibility in the 21st century: A view from the world's most successful firms. Journal of Business ethics, 48(2), 175-187.

Stanny, E., \& Ely, K. (2008). Corporate environmental disclosures about the effects of climate change. Corporate Social Responsibility and Environmental Management, 15(6), 338-348.

Sun, N., Salama, A., Hussainey, K., \& Habbash, M. (2010). Corporate environmental disclosure, corporate governance, and earnings management. Managerial Auditing Journal, 25(7), 679-700.

Suttipun, Muttanachai - Stanton, Patricia. (2012), Determinants of environmental disclosure in Thai corporate annual report, International Journal of Accounting and Financial Reporting, 2(1), 99-115.

Trireksani, T., \& Djajadikerta, H. G. (2016). Corporate governance and environmental disclosure in the Indonesian mining industry. Australasian Account Business and Finance Journal, 10(1), 18-28.

Ullmann, A. A. (1985). Data in search of a theory: A critical examination of the relationships among social performance, social disclosure, and economic performance of US firms. Academy of management review, 10(3), 540-557. 
Uwuigbe, O. R. (2011). Corporate governance and financial performance of banks: a study of listed banks in Nigeria (Doctoral dissertation, Covenant University).

Van der Laan, S. (2009). The role of theory in explaining motivation for corporate social disclosures: Voluntary disclosures vs 'solicited'disclosures. Australasian Accounting, Business and Finance Journal, 3(4), 2.

Victor Chiedu, O. B. A., \& Fodio, M. I. (2012). Board characteristics and the quality of environmental reporting in Nigeria. The Journal of Accounting and Management, (2), 33-48.

Wachira, M. (2017). Determinants of corporate social disclosures in Kenya: A longitudinal study of firms listed on the Nairobi securities exchange. European Scientific Journal, 13(11), 112-132.

Watts, R. L., \& Zimmerman, J. L. (1983). Agency problems, auditing, and the theory of the firm: Some evidence. The Journal of Law and Economics, 26(3), 613-633.

Wong, L. T., \& Fryxell, G. E. (2014). Stakeholder influences on environmental management practices: a study of fleet operations in Hong Kong (SAR), China. Transportation Journal, 43 (4), 22-35.

World Business Council for Sustainable Development. WBCSD. (2012). Sustainable development reporting: striking the balance. Hertfordshire: Earth print.

Xie, B., Davidson III, W. N., \& DaDalt, P. J. (2003). Earnings management and corporate governance: the role of the board and the audit committee. Journal of corporate finance, 9(3), 295-316.

Yakhou, M., \& Dorweiler, V. P. (2004). Environmental accounting: an essential component of business strategy. Business Strategy and the Environment, 13(2), 65-77.

Zeng, S. X., Hu, X. D., Yin, H. T., \& Tam, C. M. (2012). Factors that drive Chinese listed company's involuntary disclosure of environmental information. Journal of Business Ethics, 109 (3), 309-321. 